\title{
Physicochemical Characterization of Biofield Energy Treated Calcium Carbonate Powder
}

\author{
Mahendra Kumar Trivedi ${ }^{1}$, Rama Mohan Tallapragada ${ }^{1}$, Alice Branton ${ }^{1}$, Dahryn Trivedi ${ }^{1}$, \\ Gopal Nayak ${ }^{1}$, Omprakash Latiyal ${ }^{2}$, Rakesh Kumar Mishra ${ }^{2}$, Snehasis Jana ${ }^{2, *}$ \\ ${ }^{1}$ Trivedi Global Inc., Henderson, USA \\ ${ }^{2}$ Trivedi Science Research Laboratory Pvt. Ltd., Bhopal, Madhya Pradesh, India
}

Email address:

publication@trivedisrl.com (S. Jana)

\section{To cite this article:}

Mahendra Kumar Trivedi, Rama Mohan Tallapragada, Alice Branton, Dahryn Trivedi, Gopal Nayak, Omprakash Latiyal, Rakesh Kumar Mishra, Snehasis Jana. Physicochemical Characterization of Biofield Energy Treated Calcium Carbonate Powder. American Journal of Health Research. Vol. 3, No. 6, 2015, pp. 368-375. doi: 10.11648/j.ajhr.20150306.19

\begin{abstract}
Calcium carbonate $\left(\mathrm{CaCO}_{3}\right)$ is widely used in pharmaceutical industries and as a supplement in probiotics. The present study was designed to evaluate the effect of biofield energy treatment on the physicochemical properties of the $\mathrm{CaCO}_{3}$. The $\mathrm{CaCO}_{3}$ powder was divided into two parts and referred as control and treated. The control part was remained untreated, whereas treated part was subjected to Trivedi's biofield treatment. The control and biofield treated samples were characterized using X-ray diffraction (XRD), particle size analyzer, surface area analyzer, thermogravimetric analysis (TGA) and Fourier transform infrared spectroscopy (FT-IR). The XRD showed that the crystallite size of treated $\mathrm{CaCO}_{3}$ was increased up to $100 \%$ as compared to the control. In addition, the lattice strain was reduced in treated sample as compared to the control. The particle size analysis result showed that the average particle size was significantly changed after treatment that led to considerably enhance the specific surface area of treated $\mathrm{CaCO}_{3}$ powder by $95 \%$ as compared to the control. The FT-IR spectroscopic analysis of the treated calcium carbonate showed shifting of wavenumber attributed to symmetric stretching vibrations of carbonate ion to higher wavenumber as compared to the control. The TGA analysis showed reduction in weight loss and increase in char yield which may be due to the increase in thermal stability of the treated sample. Therefore, the biofield treatment had significantly altered the physicochemical properties of the calcium carbonate. Hence, it is assumed that treated calcium carbonate could be used as a potential supplement of probiotics for food applications.
\end{abstract}

Keywords: Biofield Energy Treatment, Calcium Carbonate, Particle Size, Surface Area, FT-IR

\section{Introduction}

The association of probiotics with wellbeing is established since time immemorial. Almost a century ago Henry Tissier reported that gut microbiota of healthy breast-fed infants were dominated by rod bifid (bifidobacteria) shaped bacteria which were absent in infants suffering from diarrhea, establishing the concept that they play a vital role to maintain human health [1]. Thus probiotics are known as microorganisms which can confer good health to host when administered in adequate amount. It was reported that human gut contains $10^{14}$ bacterial cells which is 10 folds higher than the number of cells present in the human body [2-4]. The reported beneficial effect of probiotics consumption are improvement of intestinal health, alleviate the symptoms of lactose intolerance and minimize risk of other diseases $[5,6]$.
Nevertheless, the imbalance of intestinal microbiota may cause health problems such as inflammatory bowel diseases, diarrhea, colon cancer, hypercholesterolemia, etc. [7]. There are various probiotics based products that are available in the market. Yoghurt is perhaps the most common food [8] which is used to carry probiotics to the human gut. Additionally, some other products are used to carry probiotics are calcium, cheese, fermented milk, etc. Recently it was reported that calcium helps the bacteria to stick more properly to the intestinal wall. Specifically, calcium carbonate $\left(\mathrm{CaCO}_{3}\right)$ is used commonly to lower the acid and to maintain the adherence of probiotics [9]. Zhao et al. reported that addition of alkaline salts such as calcium carbonate in skimmed milk substantially increased the viable count of $L$. bulgaricus as compared to the control sample [10]. Nevertheless, calcium carbonate has less solubility in water, hence it has less 
bioavailability in the human gastro intestinal tract. Tang et al. reported the increase in solubility of calcium when it was fermented with seven different strains of lactobacillus species [11]. Therefore some novel methods should be devised to enhance the solubility i.e. bioavailability of calcium that can improve its food applications. Recently, biofield energy treatment has effectively modified the physicochemical properties of organic product [12], drugs [13], metal [14, 15] and ceramic [16]. Due to low solubility of $\mathrm{CaCO}_{3}$ and its application as supplement in probiotics, authors wish to investigate the influence of biofield energy treatment on $\mathrm{CaCO}_{3}$.

The National Center for Complementary and Alternative Medicine (NCCAM), a part of the National Institute of Health (NIH), recommends the use of Complementary and Alternative Medicine (CAM) therapies as an alternative to the healthcare sector and about $36 \%$ of Americans regularly uses some form of CAM [17]. CAM includes numerous energyhealing therapies; biofield therapy is one of the energy medicine used worldwide to improve the health [18].

Willem Einthoven had developed electrocardiography (ECG) to measure the biofield of human body. Afterward, the Harold Saton Burr, had investigated the correlation of electric current with human body. Thus, human has the ability to harness the energy from environment/Universe and can transmit into any object (living or non-living) around the Globe. The object(s) always receive the energy and responding in a useful manner that is called biofield energy. This process is known as biofield energy treatment. Mr. Trivedi's biofield energy treatment (The Trivedi Effect ${ }^{\circledR}$ ) has known to modify the physical, atomic, and thermal characteristics of various things associated with several scientific fields such as microbiology [19], and agriculture [20].

By conceiving the above-mentioned potential of biofield energy treatment and excellent properties of calcium carbonate, this study was conducted to investigate the impact of biofield energy treatment on the physicochemical properties of calcium carbonate nanopowder.

\section{Materials and Methods}

The $\mathrm{CaCO}_{3}$ powder used in this experiment was procured from the Sigma-Aldrich. The sample was divided into two parts; one was kept as a control sample while other was subjected to Trivedi's unique biofield energy treatment and coded as treated sample. The treated group was in sealed pack and handed over to Trivedi for biofield energy treatment under standard laboratory conditions. Trivedi provided the energy treatment through his energy transmission process to the treated group without touching the sample. The control and treated samples were characterized by using X-ray diffraction (XRD), particle size analyzer, surface area analyzer, thermogravimetric analysis and Fourier transform infrared spectroscopy (FT-IR).

\subsection{X-ray Diffraction (XRD) Study}

The XRD analysis of control and treated $\mathrm{CaCO}_{3}$ were carried out on Phillips, Holland PW 1710 X-ray diffractometer system, which had a copper anode with nickel filter. The radiation of wavelength used by the XRD system was $1.54056 \AA$. The data obtained from this XRD were in the form of a chart of $2 \theta v s$. intensity and a detailed table containing peak intensity counts, d value $(\AA)$, peak width $\left(\theta^{\circ}\right)$, relative intensity $(\%)$ etc. The average crystallite size (G) was calculated by using formula:

$$
\mathrm{G}=\mathrm{k} \lambda /(\mathrm{b} \operatorname{Cos} \theta)
$$

Here, $\lambda$ is the wavelength of radiation used, $b$ is full width half-maximum (FWHM) of peaks and $\mathrm{k}$ is the equipment constant $(=0.94)$. Percentage change in average crystallite size was calculated using following formula:

\section{Percent change in average crystallite size}

$$
=\left[\left(\mathrm{G}_{\mathrm{t}}-\mathrm{G}_{\mathrm{c}}\right) / \mathrm{G}_{\mathrm{c}}\right] \times 100
$$

where, $G_{c}$ and $G_{t}$ are the average crystallite size of control and treated powder samples, respectively.

\subsection{Particle Size Analysis}

For particle size analysis, Laser particle size analyzer, Sympatec HELOS-BF was used, which had a detection range of $0 \cdot 1-875 \mu \mathrm{m}$. The data obtained from the instrument was in the form of a chart of cumulative percentage $v s$. particle size, along with a detail table containing the size and percentage of the particle present. The data obtained from four treated samples were compared with the control. The percentage change in average particle size $d_{50}$ and $d_{99}$ (size below which $99 \%$ of the particles were present) were calculated as:

$$
\begin{gathered}
\text { Percent change in particle size } \mathrm{d}_{50}(\%) \\
=\left[\left(\mathrm{d}_{50 \_\mathrm{t}}-\mathrm{d}_{50 \_} \mathrm{c}\right) / \mathrm{d}_{50 \_\mathrm{c}}\right] \times 100
\end{gathered}
$$

Here, $d_{50 t}$ and $d_{50 \text { c }}$ were the average particle size $d_{50}$ of treated and control samples respectively. Similarly the percent change in $\mathrm{d}_{99}$ was also calculated and presented.

\subsection{Surface Area Analysis}

The surface area was measured by the Surface area analyzer, SMART SORB 90 based on Brunauer-Emmett-Teller (BET), which had a detection range of $0.2-1000 \mathrm{~m}^{2} / \mathrm{g}$. The percent change in surface area was calculated as:

$$
\begin{gathered}
\text { Percent change in surface area (\%) } \\
=\left[\left(\mathrm{S}_{\mathrm{t}}-\mathrm{S}_{-} \mathrm{C}\right) / \mathrm{S}_{\mathrm{C}}\right] \times 100
\end{gathered}
$$

Here $\mathrm{S}_{\mathrm{t}}$ and $\mathrm{S}_{\mathrm{C}}$ were the surface area of treated and control samples, respectively.

\subsection{Thermogravimetric Analysis-Differential Thermal Analysis (TGA-DTA)}

The thermal stability of control and treated calcium carbonate were analyzed by using Mettler Toledo simultaneous TGA and Differential thermal analyzer (DTA). 
The samples were heated from room temperature to $400^{\circ} \mathrm{C}$ with a heating rate of $5^{\circ} \mathrm{C} / \mathrm{min}$ under air atmosphere.

\subsection{FT-IR Spectroscopy}

For FT-IR analysis, Perkin Elmer, USA Fourier Transform Infrared (FT-IR) Spectrometer with frequency range of 300$4000 \mathrm{~cm}^{-1}$ was used.

\section{Result and Discussion}

\subsection{X-ray Diffraction (XRD) Study}

XRD is a non-destructive and quantitative technique, which has been extensively used to study the crystal structure parameters of any compound. The XRD diffractogram of control and treated $\mathrm{CaCO}_{3}$ samples were presented in Fig. 1. The XRD peaks observed in control and treated sample were well matched with the reported value in Joint committee on powder diffraction Standards (JCPDS) card number 88-1807 for $\mathrm{CaCO}_{3}$ powder [21]. The most intense peak was observed at Bragg angle (20) $29.15^{\circ}$ in control; however it was found at $29.20^{\circ}, 29.33^{\circ}, 28.92^{\circ}$, and $29.01^{\circ}$ in the treated samples $\mathrm{T} 1, \mathrm{~T} 2, \mathrm{~T} 3$ and $\mathrm{T} 4$, respectively. This peak was corresponding to the crystalline plane (104) in control and treated samples. Moreover, the lattice strain along this plane was calculated using following equation:

$$
\text { Lattice strain }(\varepsilon)=\frac{\beta}{4 \tan \theta}
$$
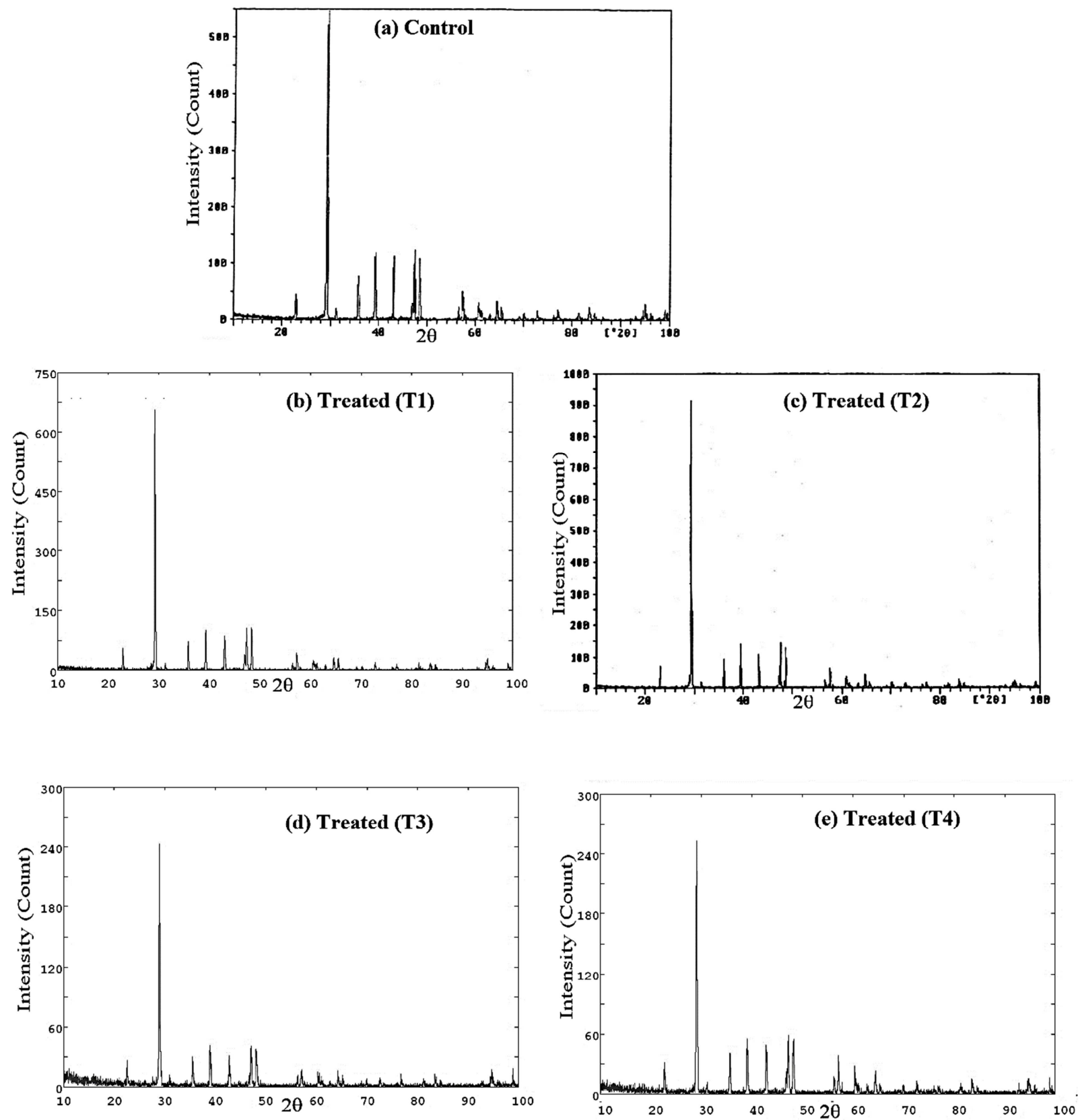

Fig. 1. XRD diffractogram of calcium carbonate powder (a) control, (b) treated (T1), (c) treated (T2), (d) treated (T3) and treated (T4). 


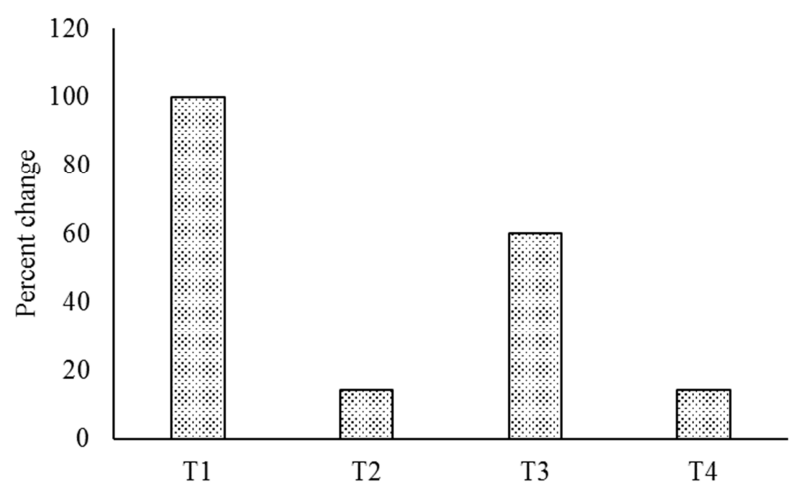

Fig. 2. Percent change in crystallite size of treated calcium carbonate powder as compared to control.

It indicated that the crystallite size was significantly increased by $100.0,14.3,59.9$, and $14.3 \%$ in T1, T2, T3 and T4, respectively as compared to the control (Fig. 2). Also, the inverse trend was observed in crystallite size and lattice strain. It was reported that the increase in temperature of $\mathrm{CaCO}_{3}$ leads to increase the crystallite size and decrease the lattice strain [22]. It is possible that the reduction in lattice strain might cause the re-orientation of the neighboring planes in the same crystalline plane and that may results into higher crystallite size in treated sample as compared to control.

Table 1. Crystallite size and lattice strain of calcium carbonate powder.

\begin{tabular}{llllll}
\hline & Control & T1 & T2 & T3 & T4 \\
\hline Crystallite size $(\mathrm{nm})$ & 53.4 & 106.9 & 61.1 & 85.5 & 61.1 \\
Lattice strain $\left(\mathrm{x} 10^{-3}\right)$ & 2.68 & 1.34 & 2.33 & 1.69 & 2.36 \\
\hline
\end{tabular}

\subsection{Particle Size Analysis}

The particle size of control and treated $\mathrm{CaCO}_{3}$ samples are presented in Table 2. The data showed that average particle size $\left(\mathrm{d}_{50}\right)$ was $48.2 \mu \mathrm{m}$ in control and it was reduced to 43.4 , 41.3 , and $41.3 \mu \mathrm{m}$ in T2, T3 and T4. However, it was slightly increased to $48.8 \mu \mathrm{m}$ in the treated $\mathrm{T} 1$ sample. It indicates that $\mathrm{d}_{50}$ was significantly reduced by $10,14.3$, and $14.3 \%$ in T2, T3, and T4, respectively as compared to the control (Fig 3). In addition, particle size $d_{99}$ (size below which $99 \%$ particles are present) was found as 101.2, 121.2, 109.4, 101.2, and $102.6 \mu \mathrm{m}$ in control, T1, T2, T3, and T4 respectively. It indicated that $\mathrm{d}_{99}$ was increased by $19.8,8.1$, and $1.4 \%$ in $\mathrm{T} 1, \mathrm{~T} 2$, and $\mathrm{T} 4$, respectively as compared to the control. Besides, based on reduction of $\mathrm{d}_{50}$ in $\mathrm{T} 2, \mathrm{~T} 3$, and $\mathrm{T} 4$, through it was not changed in T3. It is assumed that the treated particles might be fractured and broken into finer particles as compared to the control.

However, to break the particles, a sufficient amount of stress energy is required and that depends upon the size and the type of material $[23,24]$. Typically, the $\mathrm{CaCO}_{3}$ powder exists as primary particles, which linked to each other through solid bonding. Muller et al. reported that stress energy required to breaking down the primary particles is much higher than the aggregates and agglomerates [25]. It is possible that the energy, which probably transferred through biofield treatment induce the milling in treated $\mathrm{CaCO}_{3}$ sample. Nevertheless, the particle size $d_{99}$ was enlarged in most of the treated samples, which was contrary to the reduction of $\mathrm{d}_{50}$ after treatment. It is assumed that cold welding and agglomeration process took place in treated $\mathrm{CaCO}_{3}$ samples [26]. Further, the effect of change in particle size through biofield energy treatment on surface area was examined.

Table 2. Particle size and surface area of calcium carbonate powder.

\begin{tabular}{llllll}
\hline Parameter & Control & T1 & T2 & T3 & T4 \\
\hline $\mathrm{d}_{50}(\mu \mathrm{m})$ & 48.2 & 48.8 & 43.4 & 41.3 & 41.3 \\
$\mathrm{~d}_{99}(\mu \mathrm{m})$ & 101.2 & 121.2 & 109.4 & 101.2 & 102.6 \\
Surface area $\left(\mathrm{m}^{2} / \mathrm{g}\right)$ & 0.30 & 0.58 & 0.44 & 0.43 & $\mathrm{ND}$ \\
\hline
\end{tabular}

ND: Not detected

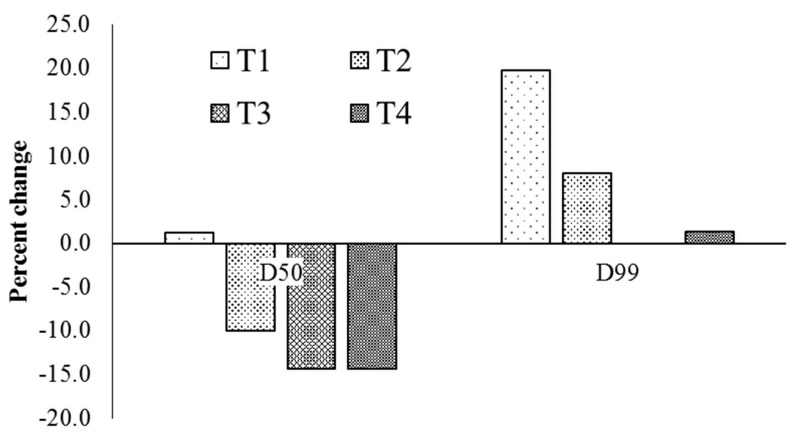

Fig. 3. Effect of biofield energy treatment on the particle size calcium carbonate.

\subsection{Surface Area Analysis}

The specific surface area analysis of control and treated samples are illustrated in Table 2. It was observed that the surface area was increased from $0.30 \mathrm{~m}^{2} / \mathrm{g}$ (control) to 0.58 , 0.44 , and $0.43 \mathrm{~m}^{2} / \mathrm{g}$ in $\mathrm{T} 1, \mathrm{~T} 2$, and $\mathrm{T} 3$, respectively. It indicates that the surface area was significantly increased by $95 \%, 50 \%$ and $45 \%$ in $\mathrm{T} 1, \mathrm{~T} 2$ and $\mathrm{T} 3$, respectively as compared to the control (Fig. 4).

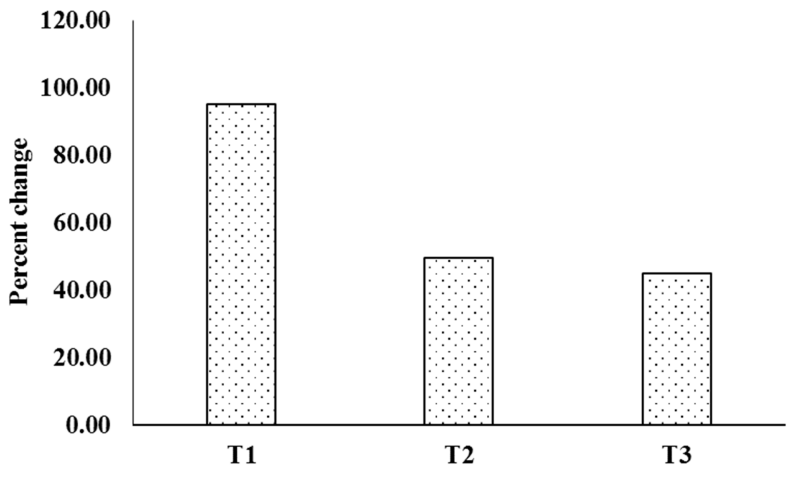

Fig 4. Effect of biofield energy treatment on the surface area of calcium carbonate.

The increase of surface area of treated $\mathrm{CaCO}_{3}$ samples $\mathrm{T} 2$ 
and $\mathrm{T} 3$ could be due to decrease in particle size. However, the increase of surface area and the particle size in treated sample (T1) was quite unexpected, since both parameter are inversely proportional to each other i.e. the smaller the particles size, larger the surface area and vice versa. Thus, based on this, treated samples T2 and T3 were supported by the particle size result. Besides, the surface area of $\mathrm{CaCO}_{3}$ play an important role in controlling the bioavailability in human body. Noyes-Whitney proposed the relationship between rate of dissolution (R) and surface area $(\mathrm{S})$ of a solid as following [27]:

$$
R=\frac{D S\left(C_{S}-C\right)}{L}
$$

Where, D is diffusion constant, $\mathrm{Cs}$ and $\mathrm{C}$ are the concentration in the bulk dissolution medium and diffusion layer surrounding the solid, respectively, L is diffusion layer thickness. The equation suggested that the rate of dissolution of a compound can be modified through altering the surface area. The bioavailability of calcium from food is an important concern because calcium intake in our food is low and most of the calcium available in food is chemically bonded to other dietary constituents and must be released in a soluble form [28-30]. Hence, in this regard, the significant increase of surface area in treated $\mathrm{CaCO}_{3}$ could increase the rate of dissolution in human gastro intestinal tract. Thus, the higher dissolution of treated $\mathrm{CaCO}_{3}$ in the human gastric fluid, make it easily available for absorption in the body and that may lead to increase the bioavailability of the treated $\mathrm{CaCO}_{3}$ as compared to the control. It is assumed that high dissolution of calcium carbonate might improve its potential as probiotic supplement for food applications.
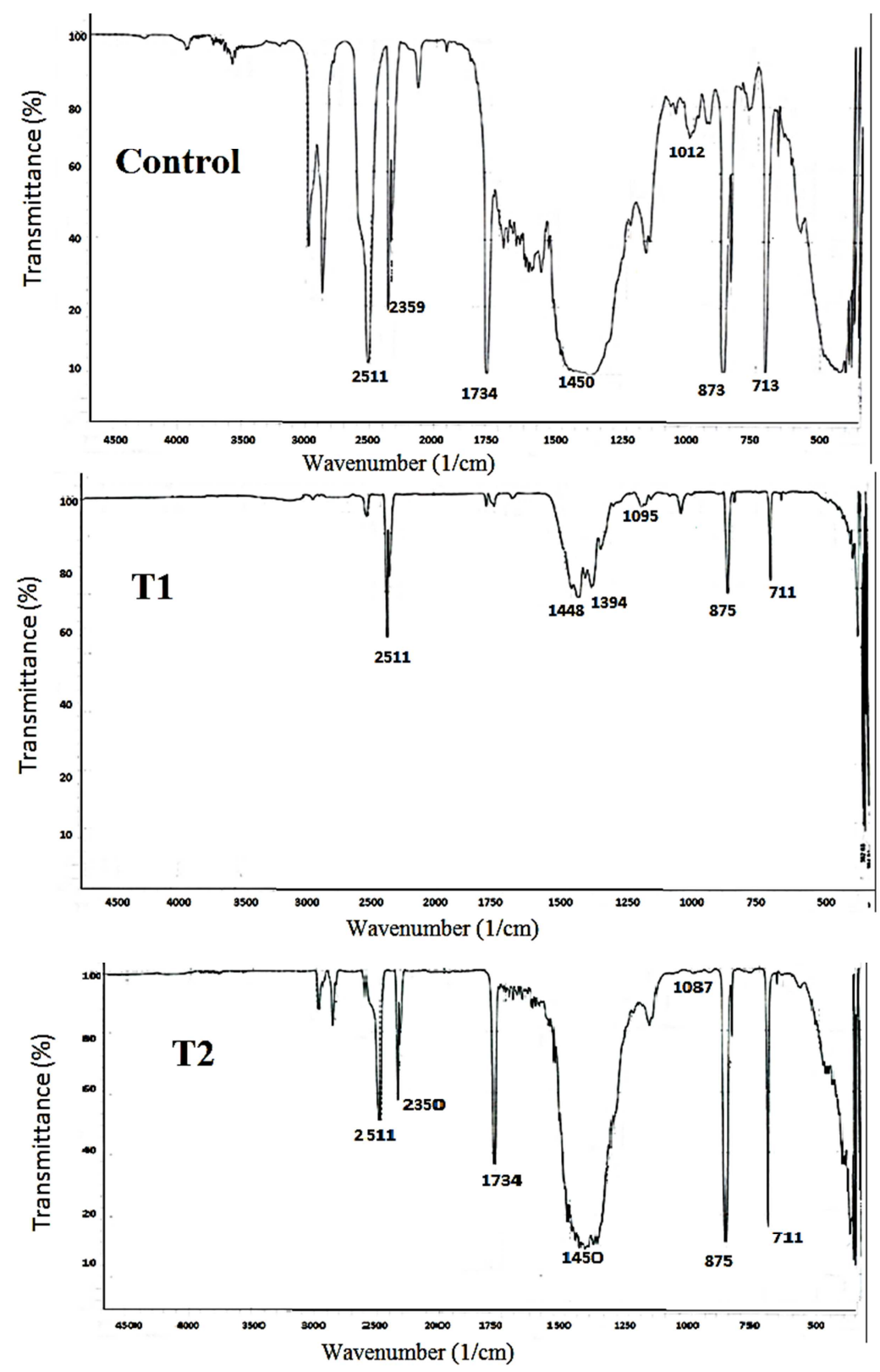

Fig. 5. FT-IR spectra of calcium carbonate powder. 


\subsection{FT-IR Spectroscopy}

The FT-IR spectra of control and treated $\mathrm{CaCO}_{3}$ samples are shown in Fig. 5. The spectra showed the absorption peak 713,711 , and $711 \mathrm{~cm}^{-1}$ in control, $\mathrm{T} 1$ and $\mathrm{T} 2$, respectively, which were attributed to in-plane bending of carbonate ion. The absorption peak observed at 873,875 , and $875 \mathrm{~cm}^{-1}$ in control, T1 and T2, respectively were ascribed to out-ofplane bending vibration of carbonate ion. Furthermore, the peak found at 1012, 1087, and $1095 \mathrm{~cm}^{-1}$ in the control, T1 and $\mathrm{T} 2$, respectively, were assigned to symmetric stretching of carbonate ions. In addition, the peak due to asymmetric stretching of carbonate ions were observed at 1450, 1448, and $1450 \mathrm{~cm}^{-1}$ in the control, T1 and T2, respectively. Thus, data suggested that that the absorption peak corresponding to symmetric stretching carbonate ion in the treated $\mathrm{CaCO}_{3}$ was shifted to higher frequency in $\mathrm{T} 1$ as compared to the control i.e. $1012 \rightarrow 1095 \mathrm{~cm}^{-1}$.

In addition, the peak attributing to asymmetric stretching of carbonate ions was shifted to higher wave number in T1 as compared to the control i.e. $1450 \rightarrow 1448 \mathrm{~cm}^{-1}$. Based on the alteration in absorption wavenumber in $\mathrm{T} 1$ and $\mathrm{T} 2$, it is assumed that the biofield treatment might alter the bond force constant in the treated calcium carbonate.

\subsection{TGA Analysis}

TGA thermogram of control and treated calcium carbonate is presented in Fig. 6. TGA thermogram of control calcium carbonate showed an onset temperature at $533^{\circ} \mathrm{C}$ and the endset temperature at $700{ }^{\circ} \mathrm{C}$. In this process, $\mathrm{CaCO}_{3}$ powder was decomposed to carbon dioxide $\left(\mathrm{CO}_{2}\right)$ and calcium oxide $(\mathrm{CaO})$. However, the thermogram of treated calcium carbonate showed similar thermal nature. The treated sample showed onset of thermal degradation at around $500^{\circ} \mathrm{C}$ and the end set of thermal degradation was noticed at around $700^{\circ} \mathrm{C}$. The percentage weight loss of the control and treated calcium carbonate was $43.20 \%$ and $39.23 \%$, respectively. Additionally, the residual char yield of the control and treated calcium carbonate was 2.92 and $3.36 \mathrm{mg}$, respectively. Hence, the result showed reduction in weight loss and increase in residual char yield of treated sample which indicated the increase in thermal stability of the treated sample as compared to the control.
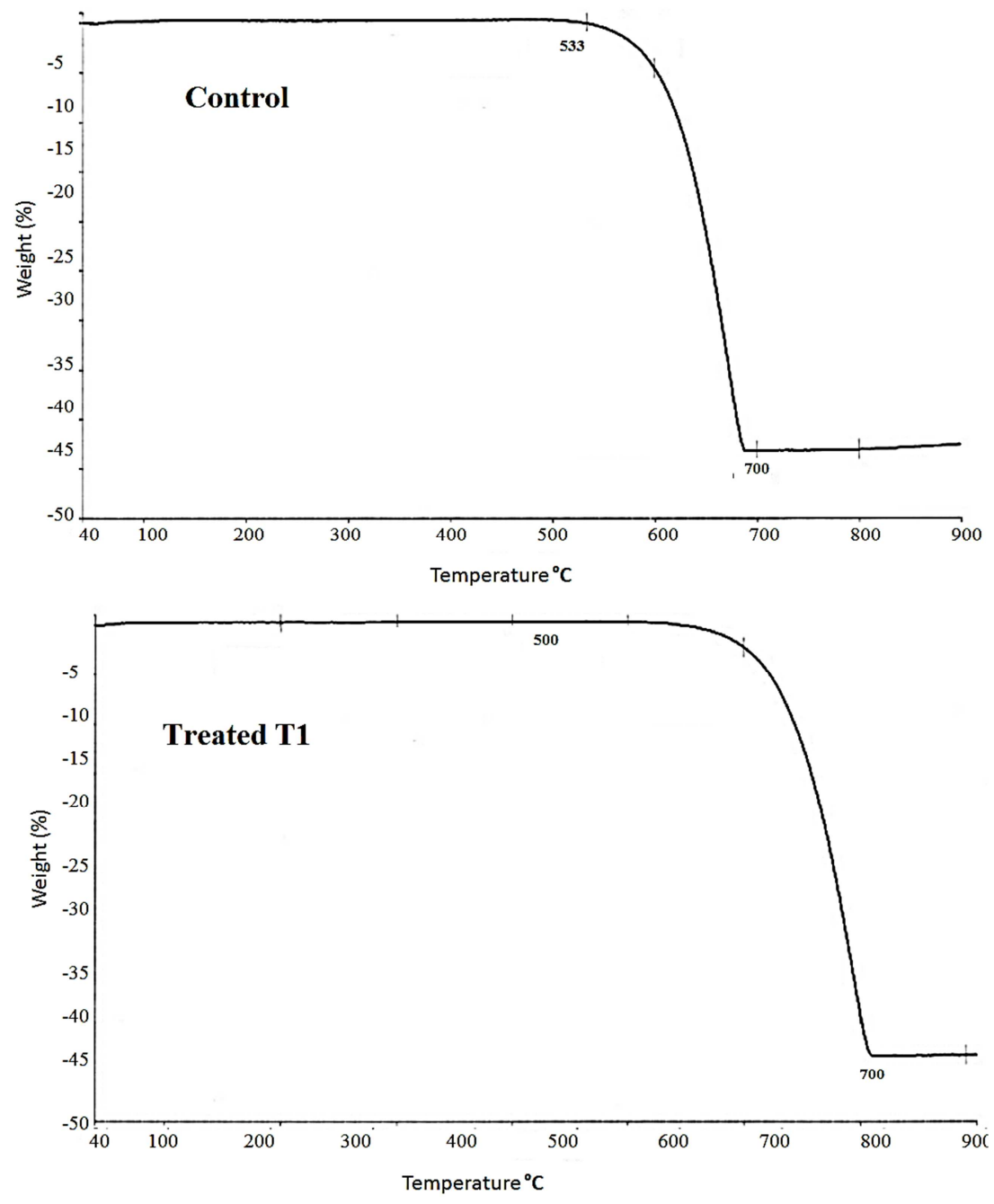

Fig. 6. TGA thermogram of calcium carbonate powder. 


\section{Conclusions}

In summary, the biofield energy treatment has significantly altered the crystallite size, particle size, and surface area of the calcium carbonate powder. The crystallite size was increased upto $100 \%$ in treated sample as compared to the control. In addition, the biofield energy treatment has significantly reduced the average particle size upto $14.3 \%$ as compared to the control. Furthermore, the surface area was significantly enhanced by $95 \%$ in treated sample as compared to the control. It indicated that the rate of dissolution of calcium carbonate in human gastric fluid might increase after biofield energy treatment. Therefore, it is assumed that the novel treated calcium carbonated with high surface area could make it a potential candidate as supplement for the probiotics food applications.

\section{Abbreviations}

XRD: X-ray diffraction; TGA: Thermogravimetric analysis; FT-IR-Fourier Transform spectroscopy; Complementary and Alternative Medicine (CAM)

\section{Acknowledgements}

The authors would like to thank all the laboratory staff of MGV Pharmacy College, Nashik for their assistance during the various instrument characterizations. The authors would also like to thank Trivedi Science, Trivedi Master Wellness and Trivedi Testimonials for their support during the work.

\section{References}

[1] Kechagia M, Basoulis D, Konstantopoulou S, Dimitriadi, D, Gyftopoulou K (2013) Health benefits of probiotics: A review. ISRN Nutr 2013: Article ID 481651.

[2] Ley RE, Peterson DA, Gordon JI (2006) Ecological and evolutionary forces shaping microbial diversity in the human intestine. Cell 124: 837-848.

[3] Savage DC (1970) Associations of indigenous microorganisms with gastrointestinal mucosal epithelia. Am J Clin Nutr 23: 1495-1501.

[4] Whitman WB, Coleman DC, Wiebe WJ (1998) Prokaryotes: The unseen majority. PNAS 95: 6578-6583.

[5] Toma MM, Pokrotnieks J (2006) Probiotics as functional food: microbiological and medical aspects. Acta Universitatis Latviensis 710: 117-129.

[6] Salminen, SJ, Gueimonde M, Isolauri E (2005) Probiotics that modify disease risk. J Nutr 135: 1294-1298.

[7] Vyas U, Ranganathan N (2012) Probiotics, Prebiotics, and Synbiotics: Gut and Beyond. Gastroenterol Res Pract 2012: Article ID 872716.
[8] Sanders ME, Gibson GR, Gill HS, Guarner F (2007) Probiotics: their potential to impact human health. CAST 36: 1-20.

[9] http://probioticsnow.com/supplements (accessed on 3rd September 2015).

[10] Zhao X, Zhang Y, Li D (2009) Elimination of acidic or oxidative stress for four probiotics with some chemicals in vitro. Afr J Microbiol Res 3: 353-357.

[11] Kressel G, Wolters M, Hahn A (2010) Bioavailability and solubility of different calcium-salts as a basis for calcium enrichment of beverages. FNSC 1: 53-58.

[12] Trivedi MK, Nayak G, Patil S, Tallapragada RM, Jana S, et al. (2015) Bio-field treatment: An effective strategy to improve the quality of beef extract and meat infusion powder. J Nutr Food Sci 5: 389.

[13] Trivedi MK, Patil S, Shettigar H, Bairwa K, Jana S (2015) Effect of biofield treatment on spectral properties of paracetamol and piroxicam. Chem Sci J 6: 98.

[14] Trivedi MK, Patil S, Tallapragada RM (2013) Effect of biofield treatment on the physical and thermal characteristics of silicon, tin and lead powders. J Material Sci Eng 2: 125.

[15] Trivedi MK, Patil S, Tallapragada RMR (2015) Effect of biofield treatment on the physical and thermal characteristics of aluminium powders. Ind Eng Manag 4: 151.

[16] Trivedi MK, Patil S, Tallapragada RM (2013) Effect of biofield treatment on the physical and thermal characteristics of vanadium pentoxide powder. J Material Sci Eng S11: 001.

[17] Barnes PM, Powell-Griner E, McFann K, Nahin RL (2004) Complementary and alternative medicine use among adults: United States, 2002. Adv Data 343: 1-19.

[18] Hammerschlag R, Jain S, Baldwin A.L, Gronowicz G, Lutgendorf S.K, et al. (2012) Biofield research: A roundtable discussion of scientific and methodological issues. Journal Altern Complement Med 18: 1081-1086.

[19] Trivedi MK, Patil S (2008) Impact of an external energy on Staphylococcus epidermis [ATCC -13518] in relation to antibiotic susceptibility and biochemical reactions - An experimental study. J Accord Integr Med 4: 230-235.

[20] Shinde V, Sances F, Patil S, Spence A (2012) Impact of biofield treatment on growth and yield of lettuce and tomato. Aust J Basic Appl Sci 6: 100-105.

[21] Hariharan M, Varghese N, Cherian AB, Sreenivasan PV, Paul $\mathrm{J}$, et al. (2014) Synthesis and characterisation of $\mathrm{CaCO}_{3}$ (Calcite) nano particles from cockle shells using chitosan as precursor. IJSRES 4: 1-5.

[22] Weiss CA, Torres-Cancel K, Moser Rd, Allison PG, Gore ER et al. (2014) Influence of temperature on calcium carbonate polymorph formed from ammonium carbonate and calcium acetate. J Nanotech Smart Mater 1: 1-6.

[23] Ohenoja K (2014) Particle size distribution and suspension stability in aqueous submicron grinding of $\mathrm{CaCO}_{3}$ and $\mathrm{TiO}_{2}$. Master Thesis, University of Oulu Finland, ISBN 978-952-620549-6. 
[24] Schilde C, Breitung-Faes S, Kwade A (2007) Dispersing and grinding of alumina nano particles by different stress mechanisms. Ceramic Forum International 84(13): 12-17.

[25] Müller F, Peukert W, Polke R, Stenger F (2004) Dispersing nanoparticles in liquids. International Journal of Mineral Processing. 74: S31-S41.

[26] Suryanarayana C (2001) Mechanical Alloying and Milling. Progress in Materials Science. 46:1-184.

[27] Dokoumetzidis A, Macheras P (2006) A century of dissolution research: From Noyes and Whitney to the biopharmaceutics classification system. Int J Pharm 321: 1-11.

[28] Allen LH (1982) Calcium bioavailability and absorption: A review. Am J Clin Nutr 35: 783-808.

[29] Allen L H (1984) Calcium absorption and requirements during the life span. Nutr News 47: 1-3.

[30] Ayed MA, Thannoun AM (2006) Calcium bioavailability of calcium carbonate based diets for male growing rats. Mesopotamia J Agric 34. 